\title{
Author Correction: Evaluating
} FAIR maturity through a scalable,
automated, community-governed framework

\begin{abstract}
Mark D. Wilkinson (D), Michel Dumontier $(\mathbb{D}$, Susanna-Assunta Sansone $\mathbb{D}$, Luiz Olavo Bonino

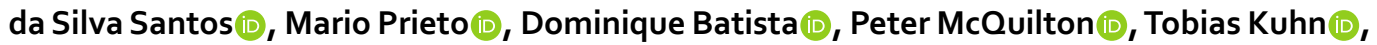
Philippe Rocca-Serra $\mathbb{D}$, Mercè Crosas $(\mathbb{D})$ \& Erik Schultes $(\mathbb{1})$
\end{abstract}

Correction to: Scientific Data https://doi.org/10.1038/s41597-019-0184-5, published online 20 September 2019

The affiliation of Mark Wilkinson and Mario Prieto was incompletely stated in the original publication. It is:

Centro de Biotecnología y Genómica de Plantas, Universidad Politécnica de Madrid (UPM) - Instituto Nacional de Investigación y Tecnología Agraria y Alimentaria (INIA), Departamento de Biotecnología-Biología Vegetal, Escuela Técnica Superior de Ingeniería Agronómica, Alimentaria y de Biosistemas, Universidad Politécnica de Madrid (UPM), Madrid, Spain

This has now been corrected in the HTML and PDF versions.

(a) Open Access This article is licensed under a Creative Commons Attribution 4.0 International By License, which permits use, sharing, adaptation, distribution and reproduction in any medium or format, as long as you give appropriate credit to the original author(s) and the source, provide a link to the Creative Commons license, and indicate if changes were made. The images or other third party material in this article are included in the article's Creative Commons license, unless indicated otherwise in a credit line to the material. If material is not included in the article's Creative Commons license and your intended use is not permitted by statutory regulation or exceeds the permitted use, you will need to obtain permission directly from the copyright holder. To view a copy of this license, visit http://creativecommons.org/licenses/by/4.0/.

(c) The Author(s) 2019 